\title{
An Unusual Case of Talon Cusp on a Geminated Tooth
}

\author{
Kaan GÜNDÜZ \\ Aydan AÇIKGÕZ
}

Department of Oral Diagnosis and Radiology, School of Dentistry, Ondokuz Mayis University, Kurupelit-Samsun, Turkey

\begin{abstract}
Talon cusp is a developmental anomaly seen on the lingual surface of anterior teeth. Gemination is an anomaly caused by a single tooth germ that attempted to divide during its development. These developmental anomalies may cause clinical problems including esthetic impairment, pain, caries and tooth crowding. This paper presents an unusual case of gemination accompanied by talon cusp in permanent dentition. The clinical and radiographic findings are described.
\end{abstract}

Key Words: tooth crown anomalies, incisor anomalies, case report, children.

\section{INTRODUCTION}

Talon cusp is an uncommon dental anomaly in which an accessory cusp-like structure projects from the cingulum area or cementoenamel junction of maxillary or mandibular anterior teeth in both primary and permanent dentitions $(1,2)$. This anomalous structure is composed of normal enamel and dentin and either has varying extensions of pulp tissue inside it or is devoid of a pulp horn.

Talon cusp is a rare entity among dental anomalies and affects both sexes either unilaterally or bilaterally. Its prevalence has been reported to be $0.06-7.7 \%$ (3), 1 $2 \%$ (4) and 3-4\% (5). The permanent dentition is more often affected than the primary dentition, the maxillary incisors being the most frequently involved teeth (6).

The accessory cusp is named as talon cusp because of its resemblance in shape to an eagle's talon. In some cases, a pyramidal or conic shape is observed (2). Because the talon cusp is composed of normal tooth structure and sometimes has varying extensions of pulp tissue inside it, a tooth with this anomaly may be overlooked as a normal tooth in radiographs (7).

The etiology of talon cusp remains unknown, but it seems to have both genetic and environmental com- ponents (8). It is believed that the talon cusp originates during the morphodifferentation stage of tooth development in which it may occur as a result of outward folding of inner enamel epithelial cells and transient focal hyperplasia of the peripheral cells of mesencymal dental papilla $(1,2)$.

Gemination is a developmental anomaly of form, which is recognized as an attempt by a single tooth germ to divide resulting in a large single tooth with bifid crown and usually common root and root canal $(7,9)$. Primary dentition is affected more frequently than the permanent dentition but there seems to be no gender differences $(7,10)$. Although its prevalence is variable in different populations, it generally ranges from 0.1 to $1 \%$ (9). Gemination is most often seen in the maxillary primary incisors and canines (9).

The etiology of geminated teeth remains unknown. Both the genetic and environmental factors are believed to play a major role in the process of gemination (11).

Talon cusp on a geminated tooth is a very rare occurrence (10). This paper presents an unusual case of gemination accompanied by talon cusp in the permanent dentition. The clinical and radiographic findings are described.

Correspondence: Dr. Kaan Gündüz, Department of Oral Diagnosis and Radiology, Faculty of Dentistry, Ondokuz Mayis University, 55139 Kurupelit Samsun, Turkey. Tel: +90-36-2457-6000, j3012. Fax: +90-36-2457-6032. e-mail: kgunduz@omu.edu.tr 


\section{CASE REPORT}

An 11 year-old male patient was admitted to the Department of Oral Diagnosis and Radiology complaining of large, unsightly maxillary central incisors. No other member of the family was affected by similar dental anomalies and there was no history of orofacial trauma. The patient was healthy and had normal physical development for his age (Fig. 1).

Intraoral examination revealed gingivitis in the anterior region. The patient's occlusion showed a Class I molar relationship and related to crowding in maxillary anterior region. The canines were buccally displaced.

The permanent maxillary right central incisor had a large and bifid crown with talon cusp on the palatal surface (Figs. 2 and 3). Clinically, the mesiodistal width of the maxillary right central incisor was $14 \mathrm{~mm}$ while the adjacent maxillary left central incisor measured 11 mm mesiodistally. On the palatal surface, the permanent

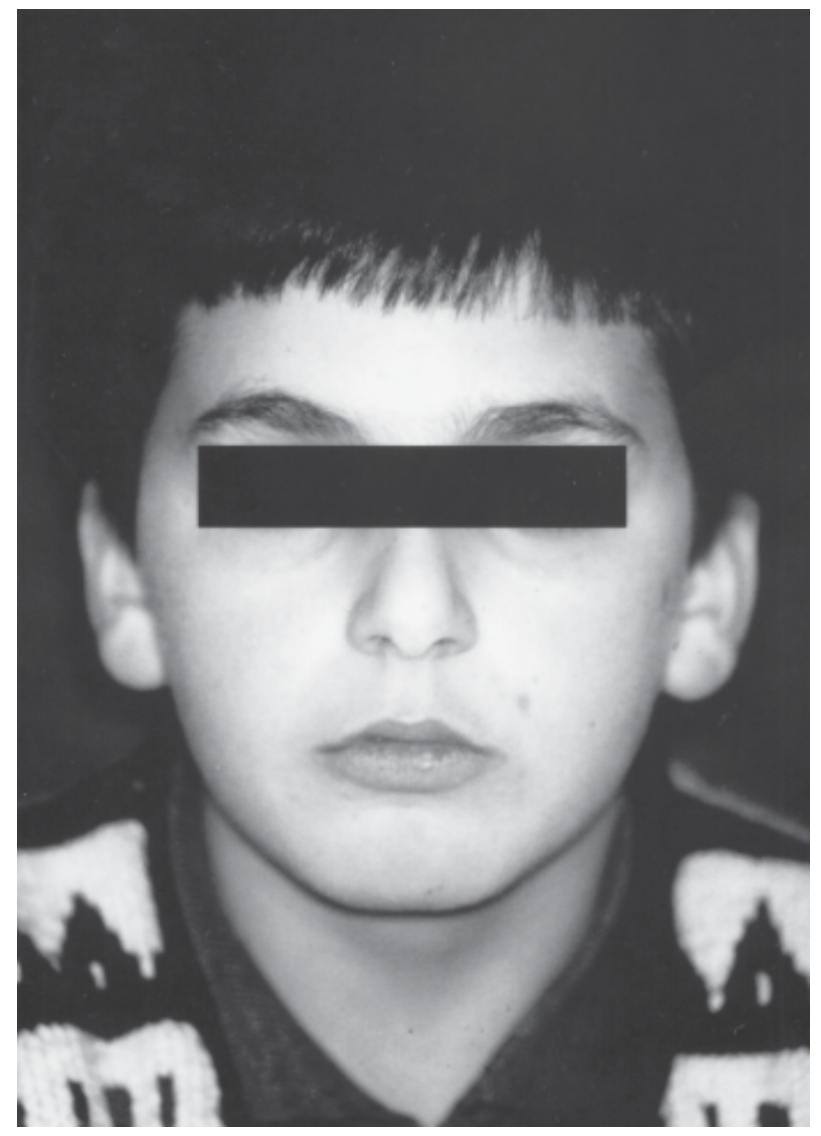

Figure 1. Extraoral appearance of the patient. right central incisor exhibited a pronounced, welldefined accessory cusp extending from the cementoenamel junction. The talon cusp was pyramidal in shape and measured $4.0 \mathrm{~mm}$ in length (incisocervically) and $3.1 \mathrm{~mm}$ in width (mesiodistally) (Figs. 3 and 4). The examination of the palatal surface of the left central incisor showed a slight projection, diagnosed as cingulum hypertrophy. Non-carious developmental grooves were present at the junction of the talon cusp and the palatal surface of the tooth. Both maxillary incisors responded normally to electric and thermal pulp tests.

Panoramic and periapical radiographic interpretation showed a V-shaped superimposed radiopaque structure laid down from crown through the incisal edge of the geminated tooth (Figs. 5 and 6). A large pulp chamber and a large single root were observed in the geminated tooth but there was no pulp tissue extending into talon cusp radiographically. Based on the clinical

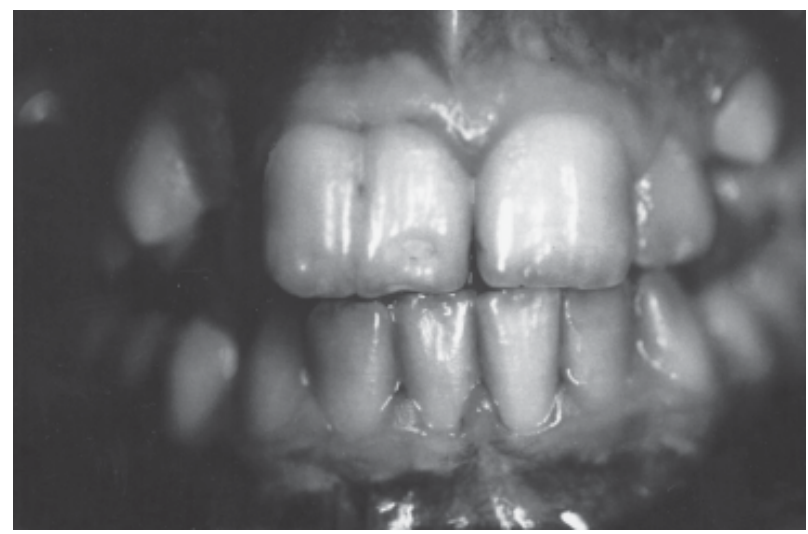

Figure 2. Buccal appearance of the maxillary permanent incisors.

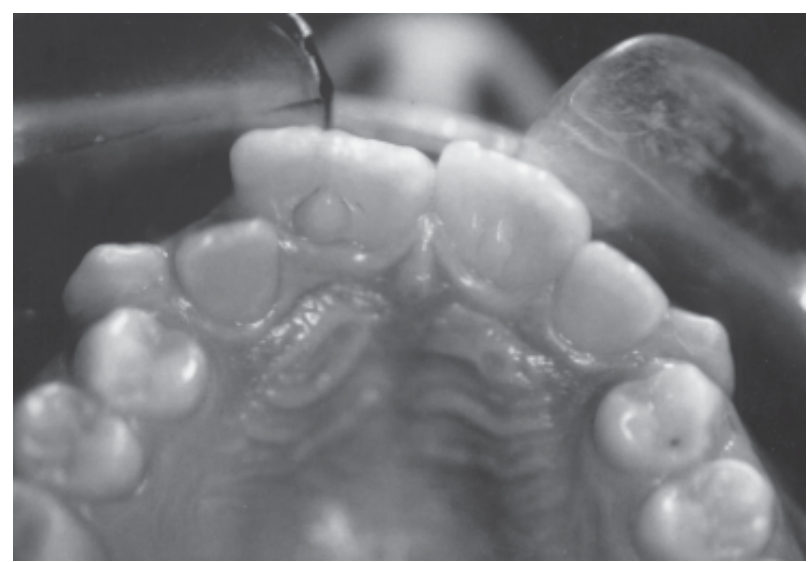

Figure 3. Palatal appearance of the maxillary permanent incisors. 
and radiographic findings, a diagnosis of talon cusp on geminated tooth was made.

After diagnosis, an orthodontist was consulted and a decision was made to extract the geminated tooth in order to provide space for the maxillary canines after root apexification of the maxillary lateral permanent incisors. The patient was scheduled for orthodontic therapy for the buccally displaced maxillary canines.

\section{DISCUSSION}

There are no specific criteria describing the talon cusp, which is a type of developmental dental anomalies. The tubercle that has different shape and dimension is often named as cingulum hypertrophy (6). Mader (6) suggests that the term talon cusp should only be used to describe anomalous cusps of permanent incisors that project prominently from the lingual surface of the

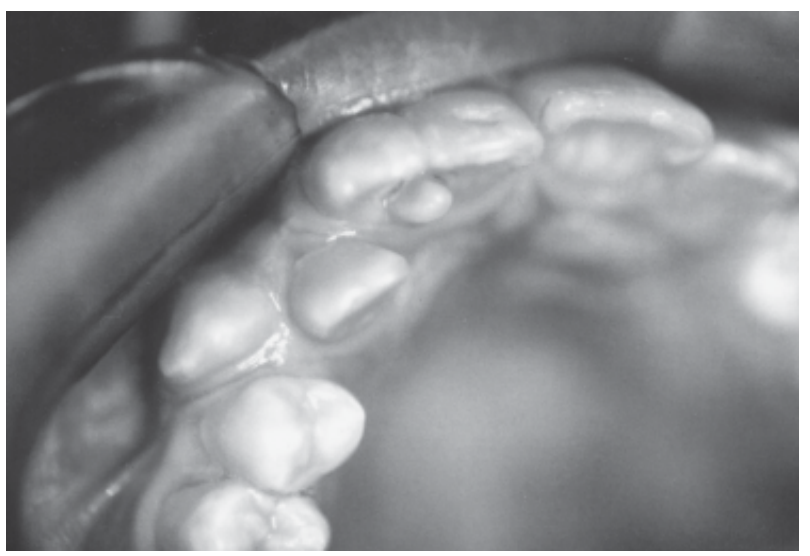

Figure 4. Palatal view showing the talon cusp in detail.

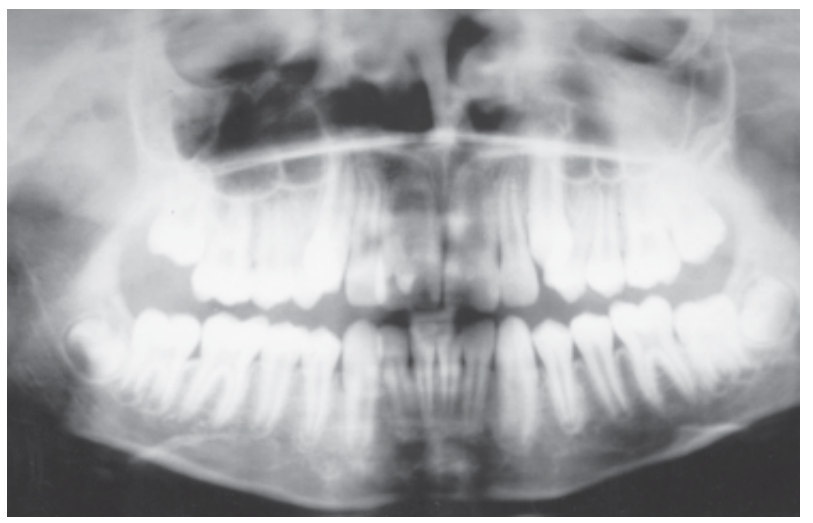

Figure 5. Panoramic radiograph. tooth, are morphologically well-delineated and extend at least half-way from the cementoenamel junction to the incisal edge. However, Davis (8) reported that when the tubercle is deviated, it is not always necessary to reach the midline because of the tubercle makes a slope to mesial $(6,8)$. Although the lateral incisors are the most frequently affected teeth in the permanent dentition, in the present case, the tubercle localized on the palatal surface of the maxillary right central incisor was considered as a talon cusp, according to Mader's classification.

Despite the published data reporting that talon cusp may also present pulpal tissue, it was not observed on radiographic examination. However, radiographic tracing of pulpal configuration inside the talon cusp has inherent difficulties because the cusp is superpositioned over the affected tooth crown $(2,7)$.

Even though mesiodens, microdontia, dens evaginatus on posterior teeth, shovel-shaped incisors, dens invaginatus or Carabelli tubercule overgrowth

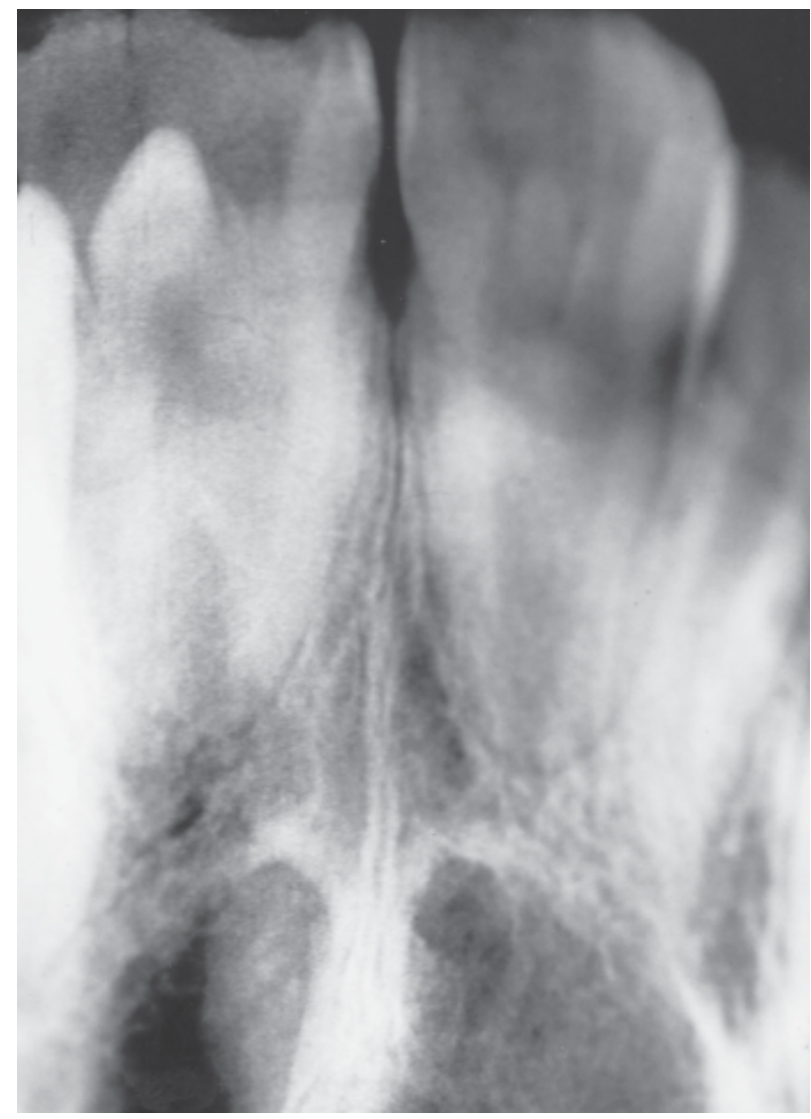

Figure 6. Periapical radiograph of the maxillary permanent incisors. 
have been reported with talon cusp (6), cases of talon cusp associated with gemination are very rare (10).

Gemination is often confused with fusion (12). Clinically and radiographically, gemination can be distinguished from fusion for presenting a single root and pulp canal,with a mirror image due to coronal groove. Tannebaum and Alling (13) described the phenomena of gemination and twinning diagrammatically. A suggested scheme of classification is as follows: Gemination (cleavage of a single tooth germ) - partial cleavage (true gemination); complete cleavage (twinning). Fusion (two separate tooth germs fused during formative stage) union by enamel and dentin (true fusion); union by dentin and/or cementum (late fusion); a late fusion by cementum is called a concrescence.

Clinical-radiographic examination and history review will usually provide enough information to make at a definite diagnosis of gemination, twinning or fusion. Additionally, the determination of total tooth number in the arch may be helpful in distinguishing between fusion and gemination. In cases of fusion, when the anomalous tooth is counted as one, tooth count reveals a missing tooth, while in gemination there is a normal tooth count. However, distinguishing gemination and fusion by tooth count alone is not a definitive parameter in all cases because fusion can occur between a normal and a supernumary tooth (10). The patient described in this paper had the afore-mentioned features and therefore the anomaly affecting the maxillary right central incisor was diagnosed as gemination. The review of literature related with talon cusp and gemination reveals that the treatment plan also shows differences according to the characteristics of each case $(2,6,14)$.

The occurrence of talon cusp caused a number of clinical problems to the patient described in this paper, including poor esthetics, occlusal interference, displacement of the affected tooth, caries-susceptible developmental grooves, attrition, irritation of the tongue and interference with tongue space. Early diagnosis of talon cusp is important and, in most cases, a definitive treatment is required. If the grooves are decayed, the lesion should be removed and the cavity restored. In case of premature contact and occlusal interference, the talon cusp should be reduced gradually on consecutive visits over 6- to 8-week intervals in order to allow time for deposition of reparative dentin for pulpal protection.

Reports describing the treatment of gemination are scant and inconclusive because this condition is not usual, particularly in the permanent dentition (7). In the presented case, due to the esthetic complaints related to gemination and lack of space for the maxillary canines, the geminated tooth was scheduled for extraction.

\section{RESUMO}

Cúspide em garra (talon cusp) é uma anomalia de desenvolvimento que occore na face lingual de dentes anteriores. Geminação é uma anomalia causada quando um germe dental tenta se dividir durante a fase de desnvolvimento. Estas anomalias de desenvolvimento podem causar problemas clínicos tais como comprometimento estético, dor, cárie e apinhamento dental. Este artigo relata um caso incomum de geminação acompanhado de cúspide em garra (talon cusp) na dentição permemente. Os achados clínicos e radiográficos são descritos.

\section{REFERENCES}

1. Hattab FN, Yassin OM, Al-Nimri KS. Talon cusp - Clinical significance and management: Case reports. Quintessence Int 1995;26:115-120.

2. Hattab FN, Yassin OM, Al-Nimri KS. Talon cusp in permanent dentition associated with other dental anomalies: review of literature and reports of seven cases. ASDC J Dent Child 1996;63:368-376.

3. Sedano HO, Carreon Freyre I, Garza de la Garza ML, Gomar Franco CM, Grimaldo Hernandez C, Hernandez Montoya ME, Hipp C, Keenan KM, Martinez Bravo J, Medina Lopez JA. Clinical orodental abnormalities in Mexican children. Oral Surg Oral Med Oral Pathol 1989;68:300-331.

4. Shay JC.Dens evaginatus-case report of a succesful treatment.J Endodon 1984;7:324-326

5. Curzon ME, Curzon JA, Poyton HC. Evaginatus odontomes in the Keewation Eskimo. Br Dent J 1970;12:324-328.

6. Mader CL. Talon cusp. J Am Dent Assoc 1981;103:244-246.

7. Hattab FN, Hazaa'a AM. An unusual case of talon cusp on geminated tooth. J Can Dent Assoc 2001;67:263-266.

8. Davis PJ, Brook AH. The presentation of talon cusp: diagnosis, clinical features, associations and possible etiology. $\mathrm{Br}$ Dent J 1985;159:84-88.

9. Duncan WK, Helpin ML. Bilateral fusion and gemination: A literature analysis and case report.Oral Surg 1987;64:82-87.

10. Cullen CL, Pangrazio-Kulbersh V. Bilateral gemination with talon cusp: report of case. J Am Dent Assoc 1985;111:58-59.

11. Yuen SWH, Chan JCY, Wei SHY. Double primary teeth and their relationship with the permanent successors: a radiographic study of 376 cases. Pediatr Dent 1987;9:42-48.

12. Ferraz JA, de Carvalho Junior JR, Saquy PC, Pecora JD, SousaNeto MD. Dental anomaly: dens evaginatus (talon cusp). Braz Dent J 2001;12:132-134.

13. Tannenbaum KA, Alling EE. Anomalous tooth development: case report of gemination and twinning. Oral Surg 1963;16:883-887.

14. Pereira AJ, Fidel RA, Fidel SR. Maxillary lateral incisor with two root canals: fusion, gemination or dens invaginatus? Braz Dent J 2000;11:141-146. 